\title{
Global gene expression profiling in human lung cells exposed to cobalt
}

\author{
Veronique Malard*, Frederic Berenguer, Odette Prat, Sylvie Ruat, \\ Gerard Steinmetz and Eric Quemeneur
}

Address: Service de Biochimie et Toxicologie Nucléaire, DSV/iBEB, CEA VALRHO, B.P. 17171, 30207 Bagnols-sur-Cèze, France

Email: Veronique Malard* - veronique.malard@cea.fr; Frederic Berenguer - frederic.berenguer@cea.fr; Odette Prat - odette.prat@cea.fr; Sylvie Ruat - sylvie.ruat@cea.fr; Gerard Steinmetz - gerard.steinmetz@cea.fr; Eric Quemeneur - eric.quemeneur@cea.fr

* Corresponding author

Published: 6 June 2007

BMC Genomics 2007, 8:147 doi:10.1/86/|47|-2/64-8-147
Received: 24 October 2006

Accepted: 6 June 2007

This article is available from: http://www.biomedcentral.com//47/-2/64/8//47

(C) 2007 Malard et al; licensee BioMed Central Ltd.

This is an Open Access article distributed under the terms of the Creative Commons Attribution License (http://creativecommons.org/licenses/by/2.0), which permits unrestricted use, distribution, and reproduction in any medium, provided the original work is properly cited.

\begin{abstract}
Background: It has been estimated that more than I million workers in the United States are exposed to cobalt. Occupational exposure to ${ }^{59} \mathrm{Co}$ occurs mainly via inhalation and leads to various lung diseases. Cobalt is classified by the IARC as a possible human carcinogen (group 2B). Although there is evidence for in vivo and in vitro toxicity, the mechanisms of cobalt-induced lung toxicity are not fully known. The purpose of this work was to identify potential signatures of acute cobalt exposure using a toxicogenomic approach. Data analysis focused on some cellular processes and protein targets that are thought to be relevant for carcinogenesis, transport and biomarker research.
\end{abstract}

Results: A time course transcriptome analysis was performed on A549 human pulmonary cells, leading to the identification of 85 genes which are repressed or induced in response to soluble 59 Co. A group of 29 of these genes, representing the main biological functions, was assessed by quantitative RT-PCR. The expression profiles of six of them were then tested by quantitative RT$P C R$ in a time-dependent manner and three modulations were confirmed by Western blotting. The 85 modulated genes include potential cobalt carriers ( $F B X L 2, Z N T I, S L C I 2 A 5$ ), tumor suppressors or transcription factors (MAZ, DLGI, MYC, $A X L)$ and genes linked to the stress response (UBC, $H S P C B, B N I P 3 L)$. We also identified nine genes coding for secreted proteins as candidates for biomarker research. Of those, TIMP2 was found to be down-regulated and this modulation was confirmed, in a dose-dependent manner, at protein level in the supernatant of exposed cells.

Conclusion: Most of these genes have never been described as related to cobalt stress and provide original hypotheses for further study of the effects of this metal ion on human lung epithelial cells. A putative biomarker of cobalt toxicity was identified.

\section{Background}

In the United States, more than a million workers are potentially exposed to cobalt or its compounds [1]. Cobalt is massively used in the steel industry, being a major constituent of hard metal alloys, in combination with tungsten carbides. Other industrial uses include diamond polishing with Co-containing disks and the production of drying agents, pigments, and catalysts [2]. 
Radioactive isotopes of cobalt are used in industry, medicine and nuclear research. In nuclear power plants, ${ }^{59} \mathrm{Co}-$ containing alloys can be activated into radioactive ${ }^{60} \mathrm{Co}$ oxides, dispersed in the cooling water and then contaminate workers $[3,4]$. A study measuring the ambient air in cobalt powder production reported concentrations of cobalt ranging from 0.675 to $10 \mathrm{mg} / \mathrm{m} 3$ [5]. Airborne concentrations measured in the working environment from a factory producing hard-metal inserts ranged from 14.6 to $37.4 \mathrm{mg} / \mathrm{m} 3$ [6]. Occupational exposure to Co occurs mainly via inhalation leading to various lung diseases, such as pneumonitis, fibrosis and asthma $[7,8]$. As with human exposure, animal exposure to cobalt-containing aerosols causes pronounced respiratory effects. A single 30-minute exposure of rats to relatively high levels (26-236 mg cobalt hydrocarbonyl/m3), resulted in lung congestion, oedema, and haemorrhage [9]. Necrosis and inflammation of the respiratory tract epithelium were reported in rats exposed to $19 \mathrm{mg}$ cobalt $/ \mathrm{m} 3$ and mice exposed to $1.9 \mathrm{mg}$ cobalt sulfate/m 3 over 16 days $[10,11]$. Some acute effects have been observed concerning general public exposure. Lethal cardiomyopathy was reported in people who consumed large quantities of beer containing cobalt as a foam stabilizer (0.04-0.14 mg cobalt $/ \mathrm{kg} /$ day), and acute mortality accounted for $18 \%$ of the deaths [12]. A 19-month-old boy who swallowed an unknown amount of cobalt chloride solution died 6.5 hours after ingestion [13].

Following absorbtion by inhalation, cobalt is eliminated in the urine. Biological monitoring of accidental exposure mainly involves measuring the concentration of metal in the urine. This might be inadequate for several reasons. Firstly, the quantity of metal excreted (exposure marker) does not necessarily reflect organ damage, which varies from one person to another. Secondly, depending on the chemical form, excretion does not necessarily reflect the level of metal in the body because some forms are retained in the lungs. Thirdly, depending on its solubility, clearance can be very rapid and the cobalt may have left the body by the time samples can be taken. Therefore, a key issue in monitoring occupational exposure is the availability of adequate biomarkers.

Although the chemical toxicity of cobalt has been proven, the molecular mechanisms of its toxicity are not all known. Cobalt is genotoxic $[14,15]$, and an oxidizing stress inducer [16]. It also induces apoptosis [17]. Cobalt is used as a hypoxia-simulating agent [18], leading to increased apoptosis, glycolysis, angiogenesis and erythropoiesis[19].

Since the lung is the main target organ of cobalt toxicity, the human A549 lung cell line was chosen as a model for this study, to evaluate cobalt toxicity. Noteworthy, this cell line has been widely documented in molecular toxicology, including hypoxia mimicked by cobalt $[16,20]$.

Microarrays are currently used for large scale gene profiling, measuring sensitive cell changes in response to xenobiotic exposure. Such investigative studies may help identify new molecular targets for toxicants or provide new hypotheses about their mechanisms of action [21]. We used toxicogenomic tools to detect biomolecular targets of acute cobalt exposure and identify candidates as biomarkers of cobalt toxicity.

\section{Results and discussion Cobalt cytotoxicity}

A549 is a stable tumor cell line, obtained from human lung carcinoma, with properties of type II alveolar epithelial cells [22]. The response of A549 cells to increasing concentrations of cobalt $(\mathrm{CoCl} 2)$ after $24 \mathrm{~h}$ exposure was first analysed using the intracellular ATP measurement that reflects early metabolic modification [23]. We determined that the concentration needed to decrease ATP concentration to $50 \%$ was reached at $2 \mathrm{mM}$ cobalt (figure 1). At this concentration, we measured an average load of 2.4 pg of cobalt per cell, using flame atomic absorption spectroscopy (data not shown). Some toxicologists, including one reviewer of this paper, assume that cytotoxic doses are too high to study specific cellular response to a toxicant [31]. The consequence, on gene modulation, could be the activation of large numbers of nonspecific pathways of toxicity, particularly a predominance of apoptosis and stress related genes. However, as the purpose of this study was to simulate accidental acute exposure, we nevertheless chose to expose A549 cells to an acute dose of cobalt (2 $\mathrm{mM})$.

\section{Differential gene expression and functional classification}

The global transcriptional response was monitored using CEA microarrays (GPL4263) [24]. A549 cells were treated with $2 \mathrm{mM}$ cobalt in a time course experiment. For each experiment, control cells were grown in parallel and collected simultaneously. At $30 \mathrm{~min}$. and $2 \mathrm{~h}$, six microarrays (three dyeswaps) were hybridized with RNA from two different cell exposures. At $4 \mathrm{~h}$, four microarrays (two dyeswaps) were hybridized with RNA from two exposures and at $24 \mathrm{~h}, 14$ microarrays (seven dyeswaps) were hybridized with RNA from three cell exposures. Details of the experimental design and microarray data were submitted to the Gene Expression Omnibus repository at the National Center for Biotechnology Information [24] and are accessible via number GSE5892. Data analysis was performed as described in the methods section. After applying our selection criteria to the data (ratio $>1.5$ and $\mathrm{p}<0.05$ ), we obtained a list of 173 modulated clones corresponding to 85 known genes. The modulation trend was up-regulation since 53 genes were up-regulated and 


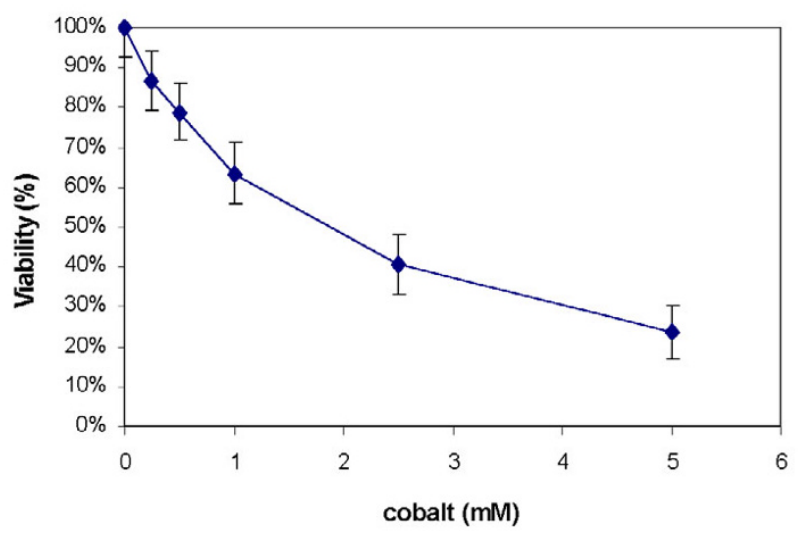

\section{Figure I}

ATP viability test on A549 cells exposed to cobalt. The cells were cultured for $24 \mathrm{~h}$ with increasing concentrations of cobalt. Cell viability was determined by ATP Celltiter-Glow Luminescence Cell Viability Assay (Promega). Measurements were made on the Lumistar Galaxy (BMG) luminometer. The viability $(\mathrm{V})$ was determined as the ATP ratio of treated cells versus control cells in \%. The results are presented as mean \pm SD ( $n=4$ to 8$)$.

32 were down-regulated (table 1 and 2). The results showed that the main effect was obtained after $24 \mathrm{~h}$ of cobalt treatment (50 genes), and to a lesser extent after 30 min (16 genes). At $2 \mathrm{~h}$ and $4 \mathrm{~h}, 11$ and 8 genes respectively were found to be modulated. Since $24 \mathrm{~h}$ was the main category in terms of modulated gene numbers, we reinforced the study for this time point by performing a total of 14 microarrays.

We used DAVID [25] web-accessible software, to obtain information from the Gene Ontology Database. We then sorted the modulated genes manually into 8 major functional classes (table 1 and 2), combining information from DAVID, SWISS-PROT and additional elements taken from the literature. The classifications of genes modulated after $30 \mathrm{~min}$ and $24 \mathrm{~h}$ of cobalt treatment were compared. At $30 \mathrm{~min}$, the main category regulated was signal transduction and trafficking (38\%) and half of the modulated genes coded for membrane proteins. This suggests strong involvement of membrane transport in the early response to cobalt exposure. The later response $(24 \mathrm{~h})$ mainly concerned protein expression and turnover (34\%), metabolism and energy (20\%), and finally signal transduction and trafficking $(16 \%)$. This different pattern indicates that after $24 \mathrm{~h}$, the cell response is established, with metabolic adaptation and strong involvement of protein translation. It can be noticed that in spite of the cytotoxic dose we used, the genes modulation trend was rather increase than decrease, indicating an active metabolic response of the cell, and also that apoptotic and stress related genes are not over represented.

\section{Quantitative RT-PCR}

We selected genes to be validated by quantitative RT-PCR (qRT-PCR) in some specific functional classes: development, differentiation and proliferation, signal transduction and trafficking, cell defense and finally gene transcription and modification. We also selected genes coding for secreted proteins as potential hits for biomarker research. Tables 1 and 2 show the results of quantitative RT-PCR validation (lines in bold) and the primers used are described in table 3 . Of the 29 genes tested, most confirmed the variation observed in the microarrays $(83 \%)$. Five genes appeared to be modulated in the opposite direction by qRT-PCR (AXL, IFNA4, DLG1, TNFRSF9 and SIN3A). Some discrepancies between the two techniques may be due to technical artefacts even if the primers were designed within the microarray cDNA sequence. For further analysis of gene modulation, we performed time-course quantitative RT-PCR on several genes: $A X L$, $U B C, F B X L 2$ and SLC12A5 (figure 2). The results show that modulation varies over time following various profiles: either diminishing at first, then increasing up to 24 $\mathrm{h}(A X L, S L C 12 A 5)$, or being induced from $2 \mathrm{~h}(U B C)$, or finally, early and continuous diminishing (FBXL2). For genes displaying temporal modulation, down-fluctuation quickly followed by up-regulation, as with $A X L$ (figure 2), a slight difference in the kinetics of different exposures could explain the opposing results we found between microarray and qRT-PCR ratios, because RNAs from different exposures were used to perform the microarray experiments and qRT-PCR. These results, revealing an oscillatory gene expression profile, suggest complex regulation pathways in response to cobalt.

\section{Hypoxia}

Cobalt is known as a "hypoxia-simulating" agent[26] and most of the literature therefore relates to this property. Hypoxia-inducible factor (HIF-1) is a transcription factor which acts as the main regulator of oxygen homeostasis and the genes it induces have mostly been described [27]. We compared this list with our results to identify modulations due to hypoxia. Strikingly, very poor overlap was observed, as only 7 of the 85 modulated genes ( $8 \%$ ) in our study matched HIF1 target genes. These 7 genes are: aldolase A (ALDOA), glucose transporter 1 (SLC2A1), glyceraldehyde 3-phosphate dehydrogenase (GAPD), lactate dehydrogenase A $(L D H A)$, proapoptotic factor (BNIP3L), phosphoglycerate kinase 1 (PGK1) and transferrin receptor (TFRC), (table 1 and 2). Like HIF1 regulated genes, they were all induced at $24 \mathrm{~h}$ by cobalt (except TFRC which was repressed at $30 \mathrm{~min}$ ), therefore our results agree with those already published and validate our system relative to previous reports, since they repre- 
Table I: Functional classification and ratios of genes up-regulated ( $>1.5$-fold) by exposure to cobalt across all time points

\begin{tabular}{|c|c|c|c|c|}
\hline Gene ID & Gene Name & Time (h) & Microarray Ratio a & qRT-PCR Ratio b \\
\hline \multicolumn{5}{|c|}{ Development, differentiation and proliferation } \\
\hline DNAJA2 & DnaJ (Hsp40) homolog, subfamily A, member 2 & 24 & 1.94 & $2.54 *$ \\
\hline OAZI & ornithine decarboxylase antizyme I & 24 & 1.68 & $2.26 *$ \\
\hline PGF & $\begin{array}{l}\text { placental growth factor, vascular endothelial growth factor-related } \\
\text { protein }\end{array}$ & 0.5 & 1.50 & $1.37^{*}$ \\
\hline STI3 & $\begin{array}{l}\text { suppression of tumorigenicity I } 3 \text { (colon carcinoma) (Hsp70 interacting } \\
\text { protein) }\end{array}$ & 24 & 1.52 & $1.59 *$ \\
\hline TNFRSF9 & tumor necrosis factor receptor superfamily, member 9 & 0.5 & 1.55 & $0.54 *$ \\
\hline \multicolumn{5}{|c|}{ Signal transduction and trafficking } \\
\hline CTNNBI & catenin (cadherin-associated protein), beta I, $88 \mathrm{kDa}$ & 24 & 1.73 & \\
\hline DLGI & discs, large homolog I (Drosophila) & 24 & 3.42 & $0.38 * * *$ \\
\hline GNB2LI & guanine nucleotide binding protein (G protein), beta polypeptide 2-like & 24 & 1.74 & $2.64 *$ \\
\hline PLA2RI & phospholipase $\mathrm{A} 2$ receptor $\mathrm{I}, 180 \mathrm{kDa}$ & 0.5 & 1.52 & \\
\hline SCAMPI & secretory carrier membrane protein I & 24 & 4.00 & \\
\hline SLCI2A5 & solute carrier family 12 , (potassium-chloride transporter) member 5 & 0.5 & 1.58 & $1.69 * * *$ \\
\hline$S L C 25 A 6$ & $\begin{array}{l}\text { solute carrier family } 25 \text { (mitochondrial carrier; adenine nucleotide } \\
\text { translocator), member } 6\end{array}$ & 24 & 1.89 & $3.12 * * *$ \\
\hline SLC2AI & solute carrier family 2 (facilitated glucose transporter), member I & 24 & 1.85 & $3.4 I *$ \\
\hline SLC6AII & solute carrier family 6 (neurotransmitter transporter, GABA), member II & 0.5 & 1.54 & \\
\hline STXBPI & syntaxin binding protein I & 0.5 & 1.53 & \\
\hline \multicolumn{5}{|c|}{ Cell defense } \\
\hline BNIP3L & BCL2/adenovirus E IB I 9 kDa interacting protein 3-like & 24 & 1.89 & $3.30 *$ \\
\hline $\mathrm{CNIH}$ & cornichon homolog (Drosophila) & 24 & 1.62 & \\
\hline IFNA4 & interferon, alpha 4 & 0.5 & 1.60 & $0.32 *$ \\
\hline MGSTI & microsomal glutathione S-transferase I & 24 & 3.80 & \\
\hline SERPINCI & $\begin{array}{l}\text { serine (or cysteine) proteinase inhibitor, clade C (antithrombin), } \\
\text { member I }\end{array}$ & 24 & 1.59 & $5.02 *$ \\
\hline \multicolumn{5}{|c|}{ Protein expression and turn-over } \\
\hline CANX & calnexin & 24 & 1.52 & \\
\hline EEFIAI & eukaryotic translation elongation factor I alpha I & 24 & 1.63 & \\
\hline EEFIG & eukaryotic translation elongation factor I gamma & 24 & 1.76 & \\
\hline EIF4AI & eukaryotic translation initiation factor $4 \mathrm{~A}$, isoform I & 24 & 1.64 & \\
\hline HSPAIA & heat shock $70 \mathrm{kDa}$ protein IA & 24 & 3.22 & \\
\hline HSPCB & heat shock $90 \mathrm{kDa}$ protein I, beta & 24 & 2.21 & $2.5 I *$ \\
\hline KIAAI940 & KIAA 940 protein & 2 & 2.09 & \\
\hline PPIA & peptidylprolyl isomerase A (cyclophilin A) & 24 & 1.59 & \\
\hline RPLI5 & ribosomal protein LI5 & 24 & 1.73 & \\
\hline RPL35A & ribosomal protein $\mathrm{L} 35 \mathrm{a}$ & 24 & 1.68 & \\
\hline RPL36AL & ribosomal protein L36a-like & 24 & 1.55 & \\
\hline SERPINHI & $\begin{array}{l}\text { serine (or cysteine) proteinase inhibitor, clade } \mathrm{H} \text { (heat shock protein } 47 \text { ), } \\
\text { member I, }\end{array}$ & 24 & 1.61 & \\
\hline SUII & putative translation initiation factor & 24 & 2.56 & \\
\hline UBA52 & ubiquitin A-52 residue ribosomal protein fusion product I & 4 & 2.22 & \\
\hline UBB & ubiquitin $B$ & 24 & 1.94 & \\
\hline UBC & ubiquitin C & 24 & 5.58 & $8.17 *$ \\
\hline WFDC2 & WAP four-disulfide core domain 2 & 24 & 1.56 & \\
\hline \multicolumn{5}{|c|}{ Gene transcription and modification } \\
\hline BHC80 & BRAF35/HDAC2 complex (80 kDa) & 24 & 1.76 & $1.85 *$ \\
\hline HOXA9 & homeo box A9 & 0.5 & 1.50 & $2.02 *$ \\
\hline SDCCAG33 & biglycan; serologically defined colon cancer antigen 33 & 0.5 & 1.51 & \\
\hline \multicolumn{5}{|c|}{ Cell structure and mobility } \\
\hline SDC3 & syndecan 3 ( $\mathrm{N}$-syndecan) & 24 & 1.62 & \\
\hline \multicolumn{5}{|c|}{ Metabolism and energy } \\
\hline AGPAT3 & I-acylglycerol-3-phosphate O-acyltransferase 3 & 24 & 1.64 & \\
\hline ALDOA & aldolase $\mathrm{A}$, fructose-bisphosphate & 24 & 2.75 & \\
\hline GAPD & glyceraldehyde-3-phosphate dehydrogenase & 24 & 3.01 & \\
\hline LDHA & lactate dehydrogenase $\mathrm{A}$ & 24 & 1.66 & \\
\hline OAT & ornithine aminotransferase (gyrate atrophy) & 24 & 3.15 & \\
\hline PGKI & phosphoglycerate kinase I & 24 & 1.77 & \\
\hline
\end{tabular}


Table I: Functional classification and ratios of genes up-regulated (> I.5-fold) by exposure to cobalt across all time points (Continued)

\begin{tabular}{|c|c|c|c|c|}
\hline SMAPI & stromal membrane-associated protein I & 24 & 1.65 & \\
\hline TKT & transketolase (Wernicke-Korsakoff syndrome) & 24 & 1.86 & \\
\hline \multicolumn{5}{|c|}{ Unknown function } \\
\hline GPM6A & glycoprotein M6A & 2 & 1.62 & \\
\hline LOCII5704 & & 24 & 1.63 & \\
\hline LTBP3 & latent transforming growth factor beta binding protein 3 & 2 & I.7I & $2.37 *$ \\
\hline
\end{tabular}

a: $\mathrm{p}$ value $<0.05$ with 1.5 fold change.

b: validation with quantitative QRT-PCR (lines in bold) :

$*$ : $p$ value $<0.005$, *** $p$ value $<0.01$, **** $p$ value $<0.05$.

Microarray $p$-values were calculated using a t-test statistical analysis (Benjamini-Hochberg FDR) on Genespring software. Pair Wise Fixed

Reallocation Randomized Test was used to calculate qRT-PCR p values with REST software.

sent an appropriate internal positive control. Recently, two transcriptomic studies of hypoxia compared the action of low oxygen with that of metal ions such as cobalt or nickel on embryonic mouse fibrobasts [28] and human liver carcinoma [29]. $21 \%$ and $28 \%$ of the genes respectively were found to be modulated by both hypoxia and cobalt. This shows that the toxic effect of cobalt is not limited to hypoxia. It should also be noted that nickel had an action closer to that of low oxygen than cobalt, with $65 \%$ common modulated genes [29]. Comparing these results with ours showed that, apart from the hypoxia genes, we had no overlap. This discrepancy might be due to differences between cell models, species and conditions of exposure (one non-lethal dose of $0.1 \mathrm{mM}$ cobalt for $24 \mathrm{~h}$ ).

\section{Stress response - apoptosis}

The HSPCB gene coding for heat shock protein 90, was induced by a factor of 2.2 at $24 \mathrm{~h}$ (table 1 ). HSP90 protein plays a major role in the stress response by preventing irreversible protein aggregation. In our previous study of the toxicogenomics of uranium [30], we noted that both HSPCB gene and HSP90 protein were strongly repressed. This protein can even be thought of as a metal "sensor", since the HSPCB gene was also reported to be modulated by other metals ( $\mathrm{Ni}, \mathrm{As}, \mathrm{Cr}, \mathrm{Cd})$ [31]. However, we did not see any change in the quantity of HSP90 in Western blotting experiments (figure 3 ). This proteome/transcriptome discordance can be explained by an increase in protein turnover associated with gene induction, resulting in a constant amount of protein being maintained in the cell. Another explanation may be that, as Gerner observed for apoptosis, HSP90 is aggregated and accumulates in the insoluble fraction of the cytosol and is not collected during protein extraction [32]. Two other genes described as HSP mediators are also induced by cobalt: ST13 and DNAJA2.

Ubiquitin is a key element in eliminating proteins via proteasome because polyubiquitinylation is the recognition signal for protein elimination $[33,34]$. The results show that ubiquitin genes were up-regulated after $24 \mathrm{~h}$ of toxic exposure (see table 1, $U B B$, ratio $1.94, U B C$, ratio 5.6) while $U B C$ gene induction was observed in the kinetics from $4 \mathrm{~h}$ with qRT-PCR (figure 2), showing that it is not an early event in cell response. The Western blot revealed protein ubiquitinylation, with the anti-ubiquitin antibody, shown by a smear at high molecular weight in the cobalt extract, indicating an accumulation of ubiquitinylated protein (figure 3). This demonstrates increased turnover of proteins involved in defense against stress, or the elimination of proteins partly damaged by the metal, or the start of apoptosis.

Cobalt has been described as an apoptosis inducer [17] and this is confirmed here by BAG1 repression and $B N I P 3 L$ induction (table 1 and 2).

\section{Tumor suppressors - transcription factors}

The protein encoded by MAZ (Myc-associated zinc finger protein), is a transcription factor involved in both the initiation and termination of target gene transcription. It binds zinc and can act as a tumor suppressor [35]. This gene is repressed early at $2 \mathrm{~h}$. Other cobalt-modulated genes code for zinc-binding proteins involved in transcription or DNA metabolism: BHC80 (BHC80 protein), NT5E (CD73) and SDCCAG33 (Teashirt homolog 1). Cobalt ions have been shown to substitute for zinc in zinc finger protein domains which control the transcription of several genes and also in zinc-DNA repair proteins, inhibiting DNA repair $[14,36,37]$.

DLG1 (disk large homolog 1) has been identified as a tumor suppressor gene in drosophila, with its mutation inducing the loss of cell polarity and neoplastic tissue growth. This gene is highly conserved. The molecular mechanism which regulates cell proliferation by DLG1 is not well known but there are arguments for implicating epithelial cell polarization in this regulation [38]. The DLG1 (disk large homolog 1) gene was strongly repressed in qRT-PCR. The anti-DLG1 antibody revealed clear depletion of DLG1 protein in Co+ samples (figure 3). This confirmed the results of the qRT-PCR.

Two tumor suppressors (MAZ and DLG1) were repressed by cobalt, and in one case (DLG1), this repression was also observed at protein level. 
Table 2: Functional classification and ratios of genes down-regulated $(<I .5$ fold) by exposure to cobalt across all time points

\begin{tabular}{|c|c|c|c|c|}
\hline Gene ID & Gene Name & Time (h) & Microarray Ratio a & qRT-PCR Ratio ${ }^{b}$ \\
\hline \multicolumn{5}{|c|}{ Development, differentiation and proliferation } \\
\hline NDRG4 & NDRG family member 4 & 24 & 0.58 & $0.29 * * *$ \\
\hline SEZ6L & seizure related 6 homolog (mouse)-like & 4 & 0.62 & \\
\hline \multicolumn{5}{|c|}{ Signal transduction and trafficking } \\
\hline ATP6VIA & ATPase, $\mathrm{H}+$ transporting, lysosomal $70 \mathrm{kDa}, \mathrm{VI}$ subunit $\mathrm{A}$ & 2 & 0.66 & \\
\hline$A X L$ & AXL receptor tyrosine kinase & 4 & 0.60 & $1.36 * * *$ \\
\hline GFRA2 & GDNF family receptor alpha 2 & 0.5 & 0.63 & $0.09 *$ \\
\hline ICAMI & intercellular adhesion molecule I (CD54), human rhinovirus receptor & 2 & 0.60 & \\
\hline IFNAR2 & interferon (alpha, beta and omega) receptor 2 & 24 & 0.61 & $0.55 * * *$ \\
\hline MAPKIO & mitogen-activated protein kinase 10 & 24 & 0.47 & $0.31 * * *$ \\
\hline SIOOA4 & SI00 calcium binding protein A4 & 2 & 0.64 & \\
\hline TFRC & transferrin receptor $(p 90, C D 7 I)$ & 0.5 & 0.50 & $0.65 *$ \\
\hline \multicolumn{5}{|c|}{ Cell defense } \\
\hline BAGI & BCL2-associated athanogene & 2 & 0.65 & $0.55 * *$ \\
\hline TNFSF6 & tumor necrosis factor (ligand) superfamily, member 6 & 4 & 0.54 & \\
\hline \multicolumn{5}{|c|}{ Protein expression and turn-over } \\
\hline CNDP2 & CNDP dipeptidase 2 (metallopeptidase M20 family) & 4 & 0.57 & \\
\hline FBXL2 & F-box and leucine-rich repeat protein 2 & 0.5 & 0.55 & $0.75 * * * *$ \\
\hline TIMP2 & tissue inhibitor of metalloproteinase 2 & 24 & 0.63 & $0.54 * * *$ \\
\hline \multicolumn{5}{|c|}{ Gene transcription and modification } \\
\hline MAZ & MYC-associated zinc finger protein (purine-binding transcription factor) & 2 & 0.28 & $0.59 * *$ \\
\hline NT5E & 5 '-nucleotidase, ecto (CD73) & 24 & 0.50 & \\
\hline PAI-RBPI & PAI-I mRNA-binding protein & 2 & 0.62 & \\
\hline SFRSI & splicing factor, arginine/serine-rich I (splicing factor 2, alternate splicing factor) & 0.5 & 0.52 & \\
\hline SIN3A & SIN3 homolog A, transcriptional regulator (yeast) & 24 & 0.63 & $2.21 *$ \\
\hline \multicolumn{5}{|c|}{ Cell structure and mobility } \\
\hline FAT2 & FAT tumor suppressor homolog 2 (Drosophila) & 4 & 0.56 & \\
\hline TUBB2 & tubulin, beta, 2 & 4 & 0.62 & \\
\hline VIL2 & villin 2 (ezrin) & 0.5 & 0.64 & \\
\hline \multicolumn{5}{|c|}{ Metabolism and energy } \\
\hline$A K R / C 3$ & aldo-keto reductase family I, member $\mathrm{C} 3$ & 24 & 0.53 & \\
\hline ALDHIAI & aldehyde dehydrogenase I family, member AI & 24 & 0.60 & \\
\hline GLCE & glucuronyl C5-epimerase & 0.5 & 0.46 & \\
\hline GPD2 & glycerol-3-phosphate dehydrogenase 2 (mitochondrial) & 4 & 0.55 & \\
\hline MTHFS & 5,10 -methenyltetrahydrofolate synthetase & 2 & 0.52 & \\
\hline \multicolumn{5}{|c|}{ Unknown function } \\
\hline C20orf30 & chromosome 20 open reading frame 30 & 2 & 0.48 & \\
\hline C20orf30 & chromosome 20 open reading frame 30 & 24 & 0.60 & \\
\hline FLJ 12806 & hypothetical protein FLJ 12806 & 0.5 & 0.64 & \\
\hline $\begin{array}{l}\text { KIAAI58 } \\
2\end{array}$ & KIAAI582 protein & 24 & 0.58 & \\
\hline
\end{tabular}

a: $p$ value $<0.05$ with 1.5 fold change.

b: validation with quantitative QRT-PCR (lines in bold) :

$*$ : $p$ value $<0.005$, ** $p$ value $<0.01$, *** $p$ value $<0.05$, **** $p$ value $<0.1$.

Microarray $\mathrm{p}$-values were calculated using a t-test statistical analysis (Benjamini-Hochberg FDR) on Genespring software. Pair Wise Fixed

Reallocation Randomized Test was used to calculate $q R T-P C R$ p values with REST software.

We noted the modulation of three genes related to MYC, a key element in oncogenic response (table 1 and 2). The first, SIN3A, known as an MYC suppressor, is induced by cobalt. The two others: NDRG4, a gene negatively regulated by $M Y C$ and $M A Z$, a MYC transcription inhibitor, are down-regulated by cobalt. These results are not clear regarding MYC up- or down-regulation, but MYC regulation pathways are complex. These results led us to hypoth- esize that MYC might be modulated by cobalt, so we tested MYC temporal modulation with qRT-PCR. Interestingly, we noted significant MYC inhibition from $30 \mathrm{~min}$ to $24 \mathrm{~h}$ (figure 2) indicating that cobalt modulates regulation pathways controlling or controlled by MYC. Liu has recently shown that MYC is involved in the carcinogenic response of mouse liver to arsenic, another toxic metal [39]. 
The AXL gene is positively modulated. Members of the AXL/UFO family of tyrosine kinases are prone to transcriptional regulation and perform various functions including regulation of cell adhesion, migration, phagocytosis, and survival. The biological consequences of $A X L$ activation are complex. AXL was initially identified as a transforming gene product, and AXL expression is indeed up-regulated in human tumors $[40,41]$.

Concerning the potential effects of cobalt on cancer development, it will be interesting to carry out further studies of the mechanisms by which cobalt induces these responses. These genes have never been linked to cobalt effects before.

\section{Transporters}

Two cobalt transporters are described in yeast: COT1 and COT2 [42]. Eleven cobalt-tolerant mutants were obtained with a common COT2 mutation, suggesting that it is involved in cobalt uptake [43]. The mutants were resistant to cobalt toxicity and cobalt was not incorporated in yeast cells. The human homolog of COT2, FBXL2, was strongly repressed in our study as early as $2 \mathrm{~h}$ and with a ratio of 0.1 at $24 \mathrm{~h}$; this is the strongest inhibition observed in time-course qRT-PCR analysis (figure 2). FBXL2 function is not very well described, but it is potentially involved in ubiquitinylation. Conklin's observations on the yeast homolog of FBXL2 [43] and our results, lead us to suggest that FBXL2 gene repression could be a cellular defense mechanism and this protein might be associated with cobalt uptake in humans.

The product of the COT1 gene is involved in the uptake of cobalt ions [44]. COT1, has a human homolog in ZNT1, coding for Zinc transporter 1 protein, probably involved in zinc transport out of the cell. ZNT1, not spotted on the microarray, was also tested in kinetics with qRT-PCR and was found to be slightly modulated with a biphasic response; first down- then up-regulated (figure 2).

The SLC12A5 gene, coding for an integral membrane K-Cl cotransporter, was repressed at $4 \mathrm{~h}$ then strongly increased at $24 \mathrm{~h}$ (qRT-PCR ratio : 4.3). The three genes, FBXL2, ZNT1 and SLC12A5, are therefore appropriate candidates for research into cobalt transport proteins in human cells and will be studied further using targeted biological approaches.

\section{Potential biomarkers and secreted proteins}

Biological monitoring of exposure to cobalt is mainly based on its concentration in urine. This method may be inadequate for two reasons. Firstly, measuring the quantity of excreted metal (exposure marker) does not necessarily reflect organ damage, which varies from one person to another. Furthermore, depending on the chemical form, excretion does not necessarily reflect the concentration of metal in the body; indeed, certain forms are eliminated in several phases; only $40 \%$ of cobalt oxides inhaled are excreted within $72 \mathrm{~h}$ [45]. In this context, only an effective biomarker could evaluate the damage and provide a valuable tool for monitoring occupational contamination in the event of accidental acute exposure or chronic exposure. We selected nine modulated genes coding for secreted proteins: ICAM1 (CD54), SERPIN C1 (antithrombin-III), IFNA4 (alpha-4 interferon), TFRC (transferrin receptor), PLA2R1 (phospholipase receptor A2), TNFSF6 (FAS ligand), WFDC2 (WAP four-disulfide core domain protein 2), LTBP3 (latent transforming growth factor beta binding protein 3) and TIMP2 (tissue inhibitor of metalloproteinase 2). To further evaluate the interest of these genes, we checked the secretion modulation of the corresponding proteins. A549 cells were exposed to cobalt in a dose-response manner, to $0.2,1$ and $2 \mathrm{mM}$, and the supernatants analysed using available immunoassays. The levels of FAS ligand, WFDC2 [46], ICAM1, antithrombin-III, alpha-4 interferon, and soluble transferrin receptor were found to be invariant or below the kit detection limit. These results indicate that most of these immunoassays were not sensitive enough to detect faint modulations. TIMP2 protein (tissue inhibitor of metalloproteinase 2) was measured using ELISA and we confirmed the modulation recorded at gene level (microarray ratio: 0.63, qRT-PCR ratio: 0.69). A strong decrease in TIMP2 supernatant concentration was noted at 1 or 2 $\mathrm{mM}$ of cobalt (figure 4). The changes in TIMP2 levels in cell supernatants between cobalt and the control were $5 \%$ for $0.2 \mathrm{mM},-57 \%$ for $1 \mathrm{mM}$ and $-72 \%$ for $2 \mathrm{mM}$. The reason for this reduction in TIMP2 can be explained as a consequence of cobalt exposure. Matrix metalloproteinases (MMPs) are a family of endopeptidases that can degrade all the components of the extracellular matrix [47]. Endogenous protease inhibitors, known as tissue inhibitors of metalloproteinase (TIMP), provide critical extracellular regulation of MMP proteolytic activities $[48,49]$, regulating tumor growth, progression, and angiogenesis in a variety of experimental cancer models and human malignancies. TIMP2 mRNA is described as being suppressed by hypoxia in endothelial cells [50]. Exposure of cells to cobalt up-regulates indirectly hypoxia-inducible genes by a mechanism which has recently been explained [51]. Therefore, TIMP-2 down-regulation might be a consequence of cobalt-simulated hypoxia. Down-regulation of TIMP2 mediated by ROS production has been observed by Rezzani in rat cardiac tissue exposed to cyclosporin [52]. Since it is known that cobalt triggers ROS production [16], TIMP2 modulation by cobalt could also be explained by this pathway.

TIMP2 protein modulation in cobalt-exposed cell supernatant corroborated the gene down-regulation observed 
Table 3: List of primers used in qRT- PCR

\begin{tabular}{|c|c|c|c|c|c|}
\hline Gene ID & Gene Name & GenBank ID & Forward primer & Reverse primer & Amplicon (bp) \\
\hline$A X L$ & $\begin{array}{l}\text { AXL receptor tyrosine } \\
\text { kinase }\end{array}$ & NM 001699 & GACCGGCCAAGTTTTACAGA & АТААССТССАСССТСАТССА & 117 \\
\hline BAGI & $\begin{array}{l}\mathrm{BCL2} \text {-associated } \\
\text { athanogene }\end{array}$ & NM 004323 & GCAGCAGTGAACCAGTTGTC & CGGTGTTTCCATTTCCTTCA & 119 \\
\hline $\mathrm{BHC} 80$ & $\begin{array}{l}\text { BRAF35/HDAC2 complex } \\
(80 \mathrm{kDa})\end{array}$ & NM 016621 & CCGAGCCGTTTGTTTAGGTA & CACTGGGGTTGGTGAAATCT & 117 \\
\hline BNIP3L & $\begin{array}{l}\mathrm{BCL} 2 / \text { adenovirus EIB } 19 \\
\mathrm{kDa} \text { interacting protein 3- } \\
\text { like }\end{array}$ & NM 020221 & ATGTTTGGCTTTGGGGCTA & CTTCACAGGTCACACGCATT & 109 \\
\hline DLGI & $\begin{array}{l}\text { discs, large homolog I } \\
\text { (Drosophila) }\end{array}$ & NM 004087 & CAGCCAGATACTCCCCAGTT & TGAGCCACGATGAAGAACAA & 89 \\
\hline DNAJA2 & $\begin{array}{l}\text { Dnal }(\mathrm{Hsp} 40) \text { homolog, } \\
\text { subfamily } \mathrm{A} \text {, member } 2\end{array}$ & NM 005880 & CCAGGGTGTGTTCGTGTAGTT & TGGGTTGATCCAGTTGTTTTC & 120 \\
\hline$F B X L 2$ & $\begin{array}{l}\text { F-box and leucine-rich } \\
\text { repeat protein } 2\end{array}$ & NM 012157 & CAGAACTGCCGAAACATTGA & CACACAGGAGGTCAGATCCA & 123 \\
\hline FIGF & $\begin{array}{l}\text { c-fos induced growth } \\
\text { factor (vascular } \\
\text { endothelial growth factor } \\
\text { D) }\end{array}$ & NM 004469 & GAACACCAGCACCTCGTACA & TGGCAAGCACTTACAACCTG & 118 \\
\hline GFRA2 & $\begin{array}{l}\text { GDNF family receptor } \\
\text { alpha } 2\end{array}$ & NM_001495 & GAGACACACGGTCACTGGAA & TCGAGGACGAGAGACTGGAG & 126 \\
\hline GNB2LI & $\begin{array}{l}\text { guanine nucleotide binding } \\
\text { protein (G protein), beta } \\
\text { polypeptide } 2 \text {-like I }\end{array}$ & NM 006098 & GGTGTCTTGTGTCCGCTTCT & CAATGTGGTTGGTCTCAGC & 119 \\
\hline HOXA9 & homeo box A9 & NM 152739 & CACCAGACGAACAGTGAGGA & ACTCCGTTACAATCAGCATTCA & 111 \\
\hline$H S P C B$ & $\begin{array}{l}\text { Heat shock protein HSP } \\
\text { 90-beta }\end{array}$ & NM 007355 & GGAGAGGAGGAGGTGGAGAC & GAGGGTTGGGGATGATGTC & 217 \\
\hline IFNA4 & interferon, alpha 4 & NM 021268 & GAAGAAATACAGCCCTTGTGC & TGAACCAGTTTTCAATCCTTCC & 114 \\
\hline IFNAR2 & $\begin{array}{l}\text { interferon (alpha, beta and } \\
\text { omega) receptor } 2\end{array}$ & NM 000874 & GTCTCGCTAAGGGCTGGAAT & AGGCAGGACGACTGTTTGAG & 94 \\
\hline LTBP3 & $\begin{array}{l}\text { latent transforming } \\
\text { growth factor beta binding } \\
\text { protein } 3\end{array}$ & NM 021070 & CCAGGGCTACAAGAGGCTTA & GGCAGACACAGCGATAGGAG & 119 \\
\hline MAPKIO & $\begin{array}{l}\text { mitogen-activated protein } \\
\text { kinase } 10\end{array}$ & NM 002753 & СTTCCCAGATTCССТСTTCC & GTAAGGCGTCGTCCACTGAT & 128 \\
\hline$M A Z$ & $\begin{array}{l}\text { MYC-associated zinc } \\
\text { finger protein (purine- } \\
\text { binding transcription } \\
\text { factor) }\end{array}$ & NM 002383 & CGGATCACCTCAACAGTCAC & ATGGCACTTTCTCCTCGTGT & 135 \\
\hline MYC & $\begin{array}{l}\text { v-myc myelocytomatosis } \\
\text { viral oncogene homolog } \\
\text { (avian)(MYC) }\end{array}$ & NM 002467 & AAAGGCCCCCAAGGTAGTTA & TTTCCGCAACAAGTCCTCTT & 103 \\
\hline NDRG4 & NDRG family member 4 & NM 020465 & ATGCTTTCCATCCACTCACC & TTCACTGCTCTCTCCCGTTT & 115 \\
\hline OAZI & $\begin{array}{l}\text { ornithine decarboxylase } \\
\text { antizyme I }\end{array}$ & NM 004152 & GAGCCGACCATGTCTTCATT & CCCGGTCTCACAATCTCAAA & 100 \\
\hline PGF & $\begin{array}{l}\text { placental growth factor, } \\
\text { vascular endothelial } \\
\text { growth factor-related } \\
\text { protein }\end{array}$ & NM 002632 & ACCCCTTGGAGGAGAGAGAC & GCATTCAGCAGGGAAACAGT & 119 \\
\hline SERPINCI & $\begin{array}{l}\text { serine (or cysteine) } \\
\text { proteinase inhibitor, clade } \\
\text { C (antithrombin), member } \\
\text { I }\end{array}$ & NM 000488 & CAATCGCCTTTTTGGAGACA & TGGACACCCATTTGTTGATG & 146 \\
\hline SIN3A & $\begin{array}{l}\text { SIN3 homolog } \mathrm{A} \text {, } \\
\text { transcriptional regulator } \\
\text { (yeast) }\end{array}$ & NM 015477 & СТСССАACTGCAAGCACATA & TCCCAACGAGATTGTCACTG & 115 \\
\hline$S L C I 2 A 5$ & $\begin{array}{l}\text { solute carrier family } 12 \text {, } \\
\text { (potassium-chloride } \\
\text { transporter) member } 5\end{array}$ & NM 020708 & CAAGGGTCCAACTTTTCCTG & GCCTCTCGGTTTCTTCCTCT & 152 \\
\hline SLC25A6 & $\begin{array}{l}\text { solute carrier family } 25 \\
\text { (mitochondrial carrier; } \\
\text { adenine nucleotide } \\
\text { translocator), member } 6\end{array}$ & NM 001636 & CTGTTTTGCACAGCCGAGTA & TTTTGACCTCTGCGTCCTCT & 87 \\
\hline
\end{tabular}


Table 3: List of primers used in qRT- PCR (Continued)

\begin{tabular}{|c|c|c|c|c|c|}
\hline SLC2AI & $\begin{array}{l}\text { solute carrier family } 2 \\
\text { (facilitated glucose } \\
\text { transporter), member I }\end{array}$ & NM 006516 & GTGGAGACTAAGCCCTGTCG & CATAGCCACCTCCTGGGATA & 128 \\
\hline STI3 & $\begin{array}{l}\text { suppression of } \\
\text { tumorigenicity } 13 \text { (colon } \\
\text { carcinoma) (Hsp70 } \\
\text { interacting protein) }\end{array}$ & NM 003932 & AGGCAGACGAACCATCAAGT & TCCGTTATCTCCGCATTTTC & 115 \\
\hline TFRC & $\begin{array}{l}\text { transferrin receptor ( } \mathrm{p} 90 \text {, } \\
\text { CD7I) }\end{array}$ & NM 003234 & CGCTGGTCAGTTCGTGATTA & TCAGGCCCATTTCCTTTATG & 134 \\
\hline TIMP2 & $\begin{array}{l}\text { tissue inhibitor of } \\
\text { metalloproteinase } 2\end{array}$ & NM 003255 & TTCATTCGTCTCCCGTCTTT & ACCAACGTGTGTGGATCAAA & 113 \\
\hline TNFRSF9 & $\begin{array}{l}\text { tumor necrosis factor } \\
\text { receptor superfamily, } \\
\text { member } 9\end{array}$ & NM 001561 & AGGGCTGTTGGGACTTTCTT & GGATGGTGTTCTTGCTTTTGA & 83 \\
\hline TUBA3 & tubulin, alpha 3 & NM 006009 & ССТАСААСТССАТССТСАССА & GTCAACATTTCAGGGCTCCA & 203 \\
\hline$U B C$ & ubiquitin $\mathrm{C}$ & NM 021009 & GGAACAGGCGAGGAAAAGTA & AACAAGAACTGCGACCCAAA & 146 \\
\hline ZNTI & $\begin{array}{l}\text { solute carrier family } 30 \\
\text { (zinc transporter), } \\
\text { member I }\end{array}$ & NM 021194 & ACCCAGAAAACCCCAGAAGT & CACTGAACCCAAGGCATCTC & 158 \\
\hline
\end{tabular}

on the microarrays and with qRT-PCR. TIMP2 modulation has never been associated with metal stress. This result is innovative and will be studied further in the biological fluids of rats exposed to different chemical forms of cobalt by inhalation.

\section{Conclusion}

This study provides the first toxicogenomic analysis of human lung cell response to acute cobalt exposure. We have confirmed that genes involved in the cobalt hypoxia response and apoptosis are modulated. We have also revealed genes linked to heat shock response and proteasome function that have already been described in other metal stress responses. Newly identified genes linked to cobalt acute toxicity include potential cobalt carriers (FBXL2, ZNT1, SLC12A5) and tumor suppressors or transcription factors $(M A Z, D L G 1, M Y C, A X L)$. Some of these genes provide new hypotheses for elucidating the mechanisms of cobalt intracellular chemical toxicity. Targeted biological approaches might confirm their biochemical role in the cobalt response.

Regarding biomarkers, we have highlighted the down-regulation of TIMP2, a gene coding for a secreted protein. TIMP2 modulation was confirmed at protein level, in a dose-dependent manner, in the supernatant of exposed A549 cells. TIMP2 provides a putative biomarker of cobalt toxicity that will be further studied on animal models.

\section{Methods}

\section{Cell culture}

The human type II epithelial cell line A549 from ATCC, was cultured as described previously [53]. At midlog phase, a medium without FCS, containing cobalt $(\mathrm{CoCl} 2$, Sigma) or not, was added for 24 hours. A CoCl2 stock solution (1 $\mathrm{M}$ in MilliQ water) was prepared extempora- neously, filtered through a sterile $0.22 \mu \mathrm{m}$ membrane and then diluted in the cell culture medium (final concentration $2 \mathrm{mM}$ ). After $30 \mathrm{mn}, 2 \mathrm{~h}, 4 \mathrm{~h}$ or $24 \mathrm{~h}$, the cells were harvested with trypsin and washed in PBS containing 1 mM EDTA. Culture supernatants for ELISA and cells for Western blot confirmations were collected after $24 \mathrm{~h}$ of exposure.

\section{Cytotoxicity studies}

Cobalt cytotoxicity was determined by measuring the intracellular ATP after $24 \mathrm{~h}$ using the Promega CelltiterGlowTM Luminescence Cell Viability Assay (four to eight replicates per concentration). The viability rate was determined as the ratio between the ATP in treated cells and control cells. Cobalt concentration in cell pellets was measured using flame atomic absorption spectroscopy (FAAS, CERECO laboratory, Nimes, France).

\section{RNA extraction}

Total RNA was isolated using the Quiagen RNeasy miniprep kit according to the manufacturer's instructions. mRNAs were prepared using the Oligotex mRNA Quiagen kit, the purification process being repeated once to eliminate any contamination. RNA concentration was determined by OD measurement (260 nm/280 nm), purity and integrity were assessed using an Agilent 2100 Bioanalyser.

\section{Microarrays and data analysis}

Microarrays were obtained from the Service de Genomique Fonctionnelle (CEA, Evry, France). Two types of DNA collections were used for preparing the cDNA arrays: a collection of 5760 full length cDNA clones from the human infant brain 1NIB library, kindly provided by Genethon, and a collection of 2304 human PCR products (400-600 bp) corresponding to specific key-words selected by direct 

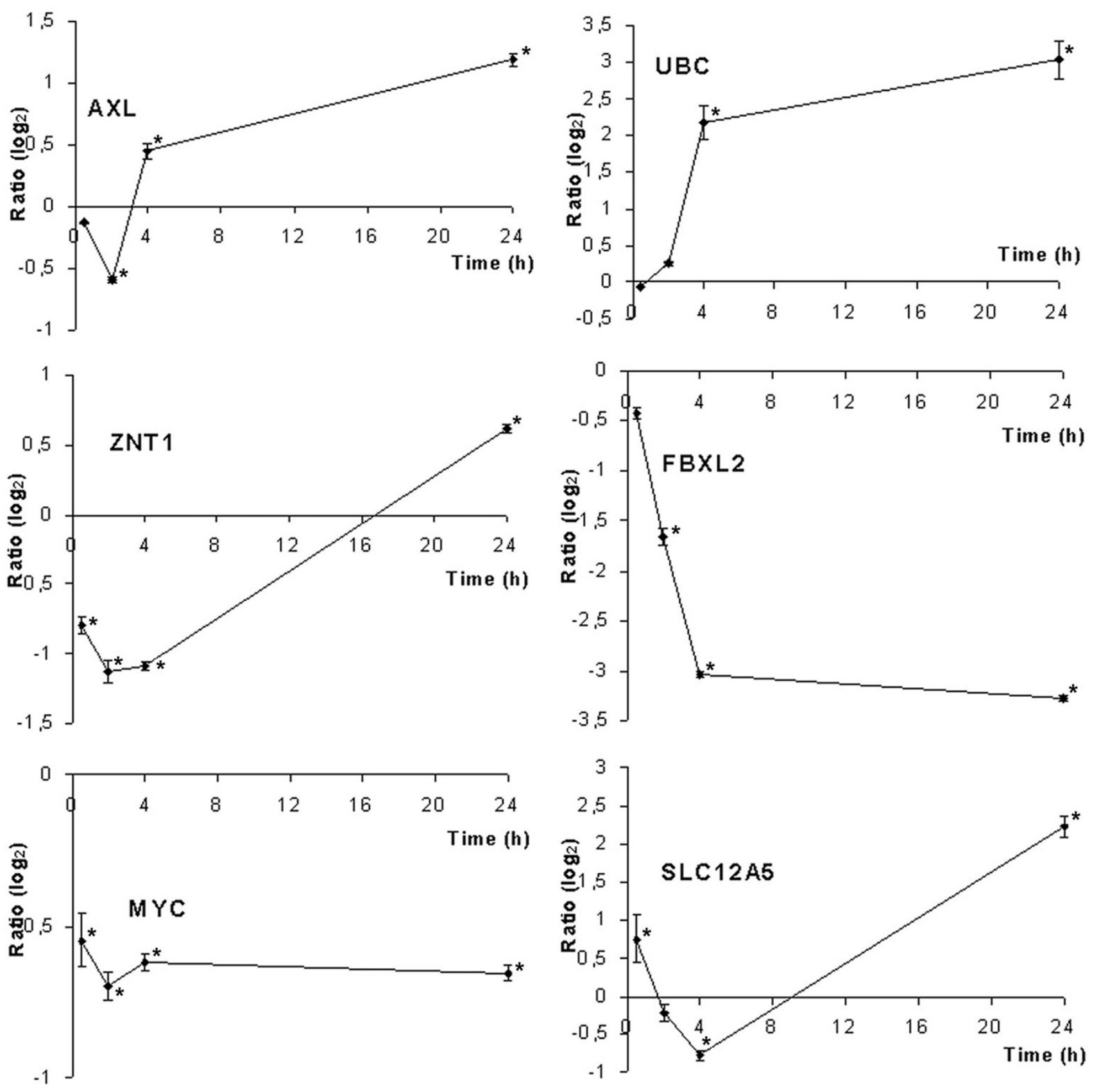

\section{Figure 2}

Time-course qRT-PCR analysis. The temporal expression pattern of genes regulated by cobalt was analysed by $\mathrm{qRT}$-PCR in sextuplets for each time point. Mean results are given in Log2 ratios \pm SD. *: significant modulation calculated by pairwise testing with $p<0.05$

query in the Unigene database. A complete description of the microarrays used in this study, including the protocols for slide production, has been submitted to the GEO database [24] under accession number GPL4263.
For each microarray experiment, $20 \mu \mathrm{g}$ of total RNA were reverse transcripted and indirectly labelled using the FairPlay Microarray Labelling Kit (Stratagene). Amino reactive Cy3- and Cy5- dyes (Cy ${ }^{\text {Tm }}$ Dye Post-Labelling Reactive Dye 


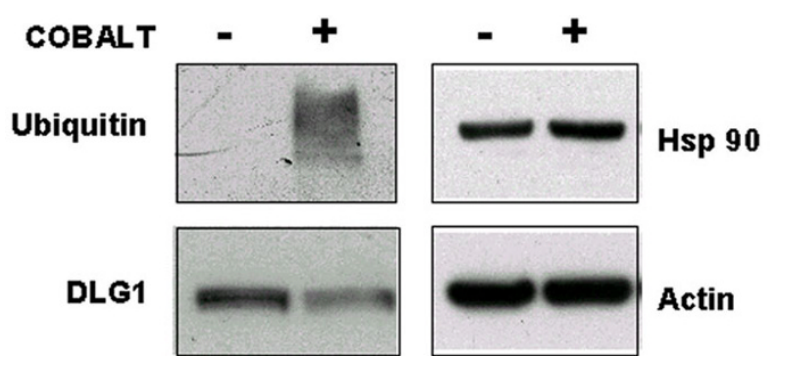

Figure 3

Western blot confirmation. Western blot analyses were performed on A549 extracts following exposure to $2 \mathrm{mM}$ cobalt for $24 \mathrm{~h}$. Treated (Co+) and control (Co-) extracts were probed with anti-ubiquitin, anti-DLGI, or anti-HSP90 antibodies. An anti-actin antibody was used as a control.

Pack, Amersham) were then chemically bound to cobalt and control cDNA respectively. Reverse labelling (or dyeswap) was performed for each experiment. Microarrays were pre-treated for 20 min with an N-methyl-pyrrolidinone solution containing $20 \mathrm{~g} / \mathrm{L}$ succinic anhydride and $20 \mathrm{mM}$ sodium borate, $\mathrm{pH} \mathrm{8,} \mathrm{immersed} \mathrm{quickly} \mathrm{in} \mathrm{etha-}$ nol and dried by centrifugation for $6 \mathrm{~min}$ at $500 \mathrm{rpm}$. Following a quick rinse in RNase-free water, the slides were prehybridized in $30 \mathrm{ml}$ 5X SSC, 1\% SDS, 1\% BSA (w/v) at $50^{\circ} \mathrm{C}$ for $40 \mathrm{~min}$. The microarrays were then rinsed in RNAse-free water, immersed quickly in isopropanol and dried by centrifugation for $6 \mathrm{~min}$ at $500 \mathrm{rpm}$. The hybridization solution was prepared using $100 \mu \mathrm{l}$ formamide, 10 $\mu \mathrm{l}$ SDS $10 \%$ and $30 \mu \mathrm{l}$ RNase-free water. Labelled cDNA was solubilized in $17.5 \mu \mathrm{l}$ of this solution plus $7.5 \mu \mathrm{l}$ of 20 $\times$ SSPE and heat-denatured. Hybridization was performed overnight at $42^{\circ} \mathrm{C}$. The microarrays were quickly rinsed in $0.1 \times$ SSC, $0.01 \%$ SDS, washed twice for $10 \mathrm{~min}$ in $0.01 \times$ SSC, then dried quickly in a stream of nitrogen and scanned with GenePix 4000B (Axon Instrument Inc., Forster City, CA). Cy3 and Cy5 spot fluorescence intensities were quantified after local subtraction of background using Genepix Pro 4.0 software (Axon Instrument Inc.). For each time point the result files were submitted to GeneSpring software 6.2 (Agilent Technologies) as follows. The data were first converted to take into account the results of the dyeswap reverse labelling, then normalized using the Lowess method, applying robust locallyweighted regression to smooth the intensity-dependence of the log ratios. The normalized data were then filtered on a quality test basis. This involved selecting spots detected on at least half of the microarrays with at least $70 \%$ pixels above threshold intensity (set to the median background plus two standard deviations).

From these remaining spots, we selected those with fluorescence ratios (representing cobalt-treated cells versus control) above 1.5 fold with $\mathrm{p}$-value $<0.05$ using a t-test

\section{TIMP2 ELISA}

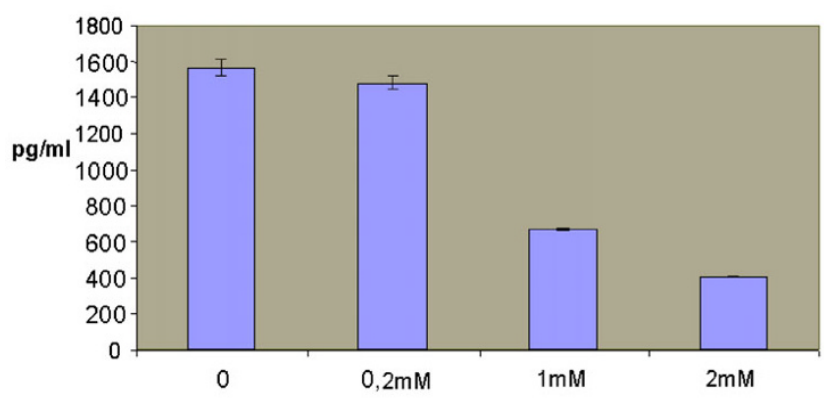

Figure 4

TIMP2 ELISA. Concentrations of TIMP2 in supernatants were determined by ELISA following treatment of A549 cells with cobalt over $24 \mathrm{~h}$. The changes in level of TIMP2 in cell supernatants between cobalt and the control were $-5 \%$ for $0.2 \mathrm{mM},-57 \%$ for I $\mathrm{mM}$ and $-72 \%$ for $2 \mathrm{mM}(\mathrm{n}=2)$.

statistical analysis on Genespring software and performing a Benjamini and Hochberg false discovery rate multiple testing correction.

\section{Quantitative real-time polymerase chain reaction (qRT- PCR)}

Specific primers were designed with Primer3 [54] using cDNA sequences spotted on microarrays, and amplicons were controlled using Mfold [55]. The list of primers is given in table 3 . Before differential analysis, good primer efficiency ( $80 \%-120 \%)$ was checked as a mandatory test. One $\mu \mathrm{g}$ of total RNA (for $30 \mathrm{~min}, 2 \mathrm{~h}$ and $4 \mathrm{~h}$ ) or $50 \mathrm{ng}$ of mRNA (for $24 \mathrm{~h}$ ) were reverse transcribed with oligo dT (12-18) using Omniscript reverse transcriptase (Qiagen) following the manufacturer's instructions. cDNA was diluted at least 10 -fold with DNase-free water to $10 \mathrm{ng} / \mu \mathrm{L}$. PCR was performed on $15 \mu \mathrm{l}$ using a DyNAmoTM HS SYBR Green qPCR Kit (Finnzymes) on a VWR DNA Engine Opticon ${ }^{\circledast} 2$ system. The amplification program consisted of 1 cycle at $95^{\circ} \mathrm{C}$ with 10 min-hold followed by 40 cycles at $95^{\circ} \mathrm{C}$ with 15 sec-hold, $60^{\circ} \mathrm{C}$ with 1 minhold, and a reading step at $60^{\circ} \mathrm{C}$ for $1 \mathrm{sec}$. Amplification was followed by melting curve analysis between $65^{\circ} \mathrm{C}$ and $95^{\circ} \mathrm{C}$. RNA was used as a negative template for the absence of residual genomic DNA and a negative control without cDNA was used to control overall specificity. House- keeping genes, which are generally used as reference genes, are often modulated by stress. For example, GAPDH is strongly induced by cobalt (ratio 3). To find an invariant gene at each time point, several candidates were selected for their invariance from all the microarray data, and tested as invariant genes in qRT-PCR. FIGF (c- fos induced growth factor) was selected for time points $0.5 \mathrm{~h}$, $2 \mathrm{~h}$ and $4 \mathrm{~h}$. For samples at $24 \mathrm{~h}, \mathrm{mRNA}$ had to be purified 
from total RNA to detect TUBA3 as an invariant reference gene. Differential analysis was performed on cDNA templates obtained from cobalt-treated or untreated cells in sextuplets for each gene, in the same way as for the reference gene ( $5 \mathrm{ng}$ for cDNA from total RNA or $0.1 \mathrm{ng}$ for cDNA from mRNA). The results were processed using REST-MCS software [56] and tested for significance using a Pair Wise Fixed Reallocation Randomized Test by calculating a $\mathrm{p}$ value. Modulation was considered to be significant when $\mathrm{p}$ calculated by REST software was $<0.05$.

\section{Western blot}

Western blots were performed as previously described [53] after $24 \mathrm{~h}$ of cobalt exposure. Cells were lysed with 7 $\mathrm{M}$ urea, $2 \mathrm{M}$ thiourea, 4\% CHAPS, $20 \mathrm{mM}$ spermine base, anti proteases (Roche cocktail), $40 \mathrm{mM}$ DTT or $50 \mathrm{mM}$ Tris- $\mathrm{HCl}, \mathrm{NaCl} 150 \mathrm{mM}$ ph7.5, $20 \mathrm{mM}$ spermine base, anti proteases, $0.5 \%$ NP40 and $1 \%$ DOC. 10 to $50 \mu \mathrm{g}$ of proteins were loaded onto a $4-12 \%$ or $12 \%$ NuPAGE gel in a MOPS or MES buffer (Invitrogen). Primary antibodies were: mouse monoclonal anti-DLG1 (sc-9961, 1/100, Santa Cruz), rabbit polyclonal anti-hsp90 $\beta$ (Ab1, 1/1666, NeoMarkers), mouse monoclonal anti- $\beta$ actin (AC-15, 1/ 2000, Sigma), or mouse monoclonal anti-ubiquitin (P4D1, 1/400, Santa Cruz). A VECTASTAIN ABC kit (Vector laboratories) or a goat anti-mouse IgG coupled to HRP (1/10000, Novagen) was used for detection.

\section{Immunoassays}

Immunoassays were performed on culture supernatants from cells exposed to various concentrations of cobalt over a $24 \mathrm{~h}$ period. The supernatants were tested crude or at 10 fold concentration. TIMP2 and FASL proteins were detected using ELISA kits (Raybiotech and R\&D systems respectively) according to the manufacturer's instructions. The WFDC2 protein, was analysed in Dr Hellström's laboratory because they developed the WFDC2 ELISA [46]. Other immunoassays were performed by the CERBA laboratory (Cergy Pontoise, France).

\section{Authors' contributions}

VM designed the study and drafted the manuscript.

FB carried out data acquisition and analysis and prepared the microarray results for tables and figures.

OP was involved in the design stage, qRT-PCR analysis and microarray experiments.

\section{SR carried out qRT-PCR.}

GS carried out the RNA extraction, labelling and microarray hybridization.
EQ was involved in the design stage and revised the manuscript

All authors read and approved the final manuscript.

\section{Acknowledgements}

This research was supported in part by "Electricité De France". We thank the Service de Genomique Fonctionnelle (CEA Evry, France) for providing us with microarrays and Dr I.Hellström (Washington University) for performing the WFDC2 ELISA test. We thank Philippe Guérin and Nicole Sage for their technical support. We thank Elisabeth Darrouzet for critical review of this manuscript and for helpful discussions.

\section{References}

I. ATSDR: toxicological profile for cobalt. 2004 [http:// www.atsdr.cdc.gov/toxprofiles/tp33.pdf].

2. Barceloux DG: Cobalt. J Toxicol Clin Toxicol 1999, 37(2):20I-206.

3. Hartmann P: Inventaire des radioexpositions [in French]. EDF - Service de radioprotection 2000, 17(Radiotoxicologie):2-5.

4. Le Guen B, Ansoborlo E: Le cobalt et ses isotopes [in French]. In Toxicologie-Pathologie professionnelle Elsevier; 2005: I-II.

5. Chlorinated drinking-water; chlorination by-products; some other halogenated compounds; cobalt and cobalt compounds. International Agency for Research on Cancer (IARC) Working Group, Lyon, 12-19 June 1990. I99I, 52:1-544.

6. Goldoni M, Catalani S, De Palma G, Manini P, Acampa O, Corradi M, Bergonzi R, Apostoli P, Mutti A: Exhaled breath condensate as a suitable matrix to assess lung dose and effects in workers exposed to cobalt and tungsten. Environ Health Perspect 2004, I I 2( I3): 1293-1298.

7. Rosenberg N: Allergie respiratoire professionnelle au cobalt. INRS 1989, 40TRI5:

8. INERIS: Cobalt et ses dérivés [in French]. fiche de données toxicologiques et environnementales des substances chimiques 2004, version I (3- décembre 04): I-52.

9. Palmes ED, Nelson N, Laskin S, Kuschner M: Inhalation toxicity of cobalt hydrocarbonyl. Am Ind Hyg Assoc J 1959, 20:453-468.

10. Bucher J: NTP technical report on the toxicity studies of Cobalt Sulfate Heptahydrate in F344/N Rats and B6C3FI Mice (Inhalation Studies) (CAS No. 10026-24-I). Toxic Rep Ser 1991, 5: I-38.

II. Bucher JR, Elwell MR, Thompson MB, Chou BJ, Renne R, Ragan HA: Inhalation toxicity studies of cobalt sulfate in $\mathrm{F344/N}$ rats and B6C3FI mice. Fundam Appl Toxicol I 990, I5(2):357-372.

12. Alexander CS: Cobalt-beer cardiomyopathy. A clinical and pathologic study of twenty-eight cases. Am J Med 1972, 53(4):395-4I7.

13. Jacobziner H, Raybin HW: Poison control...accidental cobalt poisoning. Arch Pediatr 1961, 78:200-205.

14. De Boeck M, Kirsch-Volders M, Lison D: Cobalt and antimony: genotoxicity and carcinogenicity. Mutat Res 2003, 533(I2): $135-152$

15. Lison D, De Boeck M, Verougstraete V, Kirsch-Volders M: Update on the genotoxicity and carcinogenicity of cobalt compounds. Occup Environ Med 200I, 58(10):619-625.

16. Salnikow K, Su W, Blagosklonny MV, Costa M: Carcinogenic metals induce hypoxia-inducible factor-stimulated transcription by reactive oxygen species-independent mechanism. Cancer Res 2000, 60(13):3375-3378.

17. Pulido MD, Parrish AR: Metal-induced apoptosis: mechanisms. Mutat Res 2003, 533(I-2):227-24I.

18. Bruick RK: Oxygen sensing in the hypoxic response pathway: regulation of the hypoxia-inducible transcription factor. Genes Dev 2003, I7(2I):26I4-2623.

19. Harris AL: Hypoxia--a key regulatory factor in tumour growth. Nat Rev Cancer 2002, 2(I):38-47.

20. Li Q, Chen H, Huang X, Costa M: Effects of I 2 metal ions on iron regulatory protein I (IRP-I) and hypoxia-inducible factor-I alpha (HIF-I alpha) and HIF-regulated genes. Toxicol Appl Pharmacol 2006, 2 I3(3):245-255. 
21. Lettieri T: Recent applications of DNA microarray technology to toxicology and ecotoxicology. Environ Health Perspect 2006, I I 4(I):4-9.

22. Lieber M, Smith B, Szakal A, Nelson-Rees W, Todaro G: A continuous tumor-cell line from a human lung carcinoma with properties of type II alveolar epithelial cells. Int J Cancer 1976, 17(1):62-70

23. Crouch SP, Kozlowski R, Slater KJ, Fletcher J: The use of ATP bioluminescence as a measure of cell proliferation and cytotoxicity. J Immunol Methods 1993, 160(1):8I-88.

24. Andrew AS, Warren AJ, Barchowsky A, Temple KA, Klei L, Soucy NV, O'Hara KA, Hamilton JW: Genomic and proteomic profiling of responses to toxic metals in human lung cells. Environ Health Perspect 2003, I I I (6):825-835.

25. National Center for Biotechnology Information [http:// www.ncbi.nlm.nih.gov/geo]

26. DAVID: DAVID. [http://david.abcc.ncifcrf.gov/]

27. Maxwell P, Salnikow K: HIF-I: an oxygen and metal responsive transcription factor. Cancer Biol Ther 2004, 3(I):29-35.

28. Semenza GL: Targeting HIF-I for cancer therapy. Nat Rev Cancer 2003, 3(10):72I-732.

29. Vengellur A, Woods BG, Ryan HE, Johnson RS, LaPres J]: Gene expression profiling of the hypoxia signaling pathway in hypoxia-inducible factor Ialpha null mouse embryonic fibroblasts. Gene Expr 2003, I I(3-4): I8I-197.

30. Vengellur A, Phillips JM, Hogenesch JB, LaPres JJ: Gene expression profiling of hypoxia signaling in human hepatocellular carcinoma cells. Physiol Genomics 2005, 22(3):308-3 I8.

31. Prat O, Berenguer F, Malard V, Tavan E, Sage N, Steinmetz G, Quemeneur E: Transcriptomic and proteomic responses of human renal HEK293 cells to uranium toxicity. Proteomics 2005, 5(I):297-306

32. Gerner C, Frohwein U, Gotzmann J, Bayer E, Gelbmann D, Bursch W, Schulte-Hermann R: The Fas-induced apoptosis analyzed by high throughput proteome analysis. J Biol Chem 2000, 275(50):39018-39026.

33. Bachmair A, Varshavsky A: The degradation signal in a shortlived protein. Cell 1989, 56(6): 1019-1032.

34. Hershko A, Leshinsky E, Ganoth D, Heller H: ATP-dependent degradation of ubiquitin-protein conjugates. Proc Natl Acad Sci U S A 1984, 81(6): 1619-1623.

35. Stubbs MC, Min I, Izzo MW, Rallapalli R, Derfoul A, Hall DJ: The ZF87/MAZ transcription factor functions as a growth suppressor in fibroblasts. Biochem Cell Biol 2000, 78(4):477-485

36. Kopera E, Schwerdtle T, Hartwig A, Bal W: Co(II) and Cd(II) substitute for $\mathrm{Zn}$ (II) in the zinc finger derived from the DNA repair protein XPA, demonstrating a variety of potential mechanisms of toxicity. Chem Res Toxicol 2004, I7(II): | 452-1458.

37. Witkiewicz-Kucharczyk A, Bal W: Damage of zinc fingers in DNA repair proteins, a novel molecular mechanism in carcinogenesis. Toxicol Lett 2006, I62(I):29-42.

38. Humbert P, Russell S, Richardson H: Dlg, Scribble and Lgl in cell polarity, cell proliferation and cancer. Bioessays 2003, 25(6):542-553.

39. Liu J, Xie Y, Ducharme DM, Shen J, Diwan BA, Merrick BA, Grissom SF, Tucker CJ, Paules RS, Tennant R, Waalkes MP: Global gene expression associated with hepatocarcinogenesis in adult male mice induced by in utero arsenic exposure. Environ Health Perspect 2006, I I 4(3):404-4II.

40. Nakano T, Tani M, Ishibashi Y, Kimura K, Park YB, Imaizumi N, Tsuda $\mathrm{H}$, Aoyagi K, Sasaki H, Ohwada S, Yokota J: Biological properties and gene expression associated with metastatic potential of human osteosarcoma. Clin Exp Metastasis 2003, 20(7):665-674.

41. Janssen JW, Schulz AS, Steenvoorden AC, Schmidberger M, Strehl S, Ambros PF, Bartram CR: A novel putative tyrosine kinase receptor with oncogenic potential. Oncogene I99I, 6(II):2II3-2I 20 .

42. Kobayashi M, Shimizu S: Cobalt proteins. Eur J Biochem 1999, 26I(I):I-9.

43. Conklin DS, Kung C, Culbertson MR: The COT2 gene is required for glucose-dependent divalent cation transport in Saccharomyces cerevisiae. Mol Cell Biol 1993, I3(4):204 I-2049.

44. Conklin DS, McMaster JA, Culbertson MR, Kung C: COTI, a gene involved in cobalt accumulation in Saccharomyces cerevisiae. Mol Cell Biol 1992, I2(9):3678-3688.
45. Kreyling WG, Cox C, Ferron GA, Oberdorster G: Lung clearance in Long-Evans rats after inhalation of porous, monodisperse cobalt oxide particles. Exp Lung Res 1993, 19(4):445-467.

46. Hellstrom I, Raycraft J, Hayden-Ledbetter M, Ledbetter IA, Schummer M, McIntosh M, Drescher C, Urban N, Hellstrom KE: The HE4 (WFDC2) protein is a biomarker for ovarian carcinoma. Cancer Res 2003, 63(13):3695-3700.

47. Coussens LM, Fingleton B, Matrisian LM: Matrix metalloproteinase inhibitors and cancer: trials and tribulations. Science 2002, 295(5564):2387-2392.

48. Jiang $Y$, Goldberg ID, Shi YE: Complex roles of tissue inhibitors of metalloproteinases in cancer. Oncogene 2002, 2I(14):2245-2252.

49. Baker AH, Edwards DR, Murphy G: Metalloproteinase inhibitors: biological actions and therapeutic opportunities. J Cell Sci 2002, I I 5(Pt I9):37| 9-3727.

50. Ben-Yosef $Y$, Lahat N, Shapiro S, Bitterman H, Miller A: Regulation of endothelial matrix metalloproteinase- 2 by hypoxia/reoxygenation. Circ Res 2002, 90(7):784-791.

5I. Salnikow K, Donald SP, Bruick RK, Zhitkovich A, Phang JM, Kasprzak KS: Depletion of intracellular ascorbate by the carcinogenic metals nickel and cobalt results in the induction of hypoxic stress. J Biol Chem 2004, 279(39):40337-40344.

52. Rezzani R, Giugno L, Buffoli B, Bonomini F, Bianchi R: The protective effect of caffeic acid phenethyl ester against cyclosporine A-induced cardiotoxicity in rats. Toxicology 2005 , 212(2-3): 155-164.

53. Malard V, Prat O, Darrouzet E, Berenguer F, Sage N, Quemeneur E: Proteomic analysis of the response of human lung cells to uranium. Proteomics 2005, 5( I 7):4568-4580.

54. Primer3: Primer3. Primer3 [http://frodo.wi.mit.edu/cgi-bin/primer3/ primer3 www.cgi]

55. Mfold: Mfold. [http://www.bioinfo.rpi.edu/applications/mfold/]

56. Pfaffl MW, Horgan GW, Dempfle L: Relative expression software tool (REST) for group-wise comparison and statistical analysis of relative expression results in real-time PCR - http:// www.gene-quantification.de/rest.html. Nucleic Acids Res 2002, 30(9):e36.
Publish with BioMed Central and every scientist can read your work free of charge

"BioMed Central will be the most significant development for disseminating the results of biomedical research in our lifetime. "

Sir Paul Nurse, Cancer Research UK

Your research papers will be:

- available free of charge to the entire biomedical community

- peer reviewed and published immediately upon acceptance

- cited in PubMed and archived on PubMed Central

- yours - you keep the copyright
BioMedcentral 